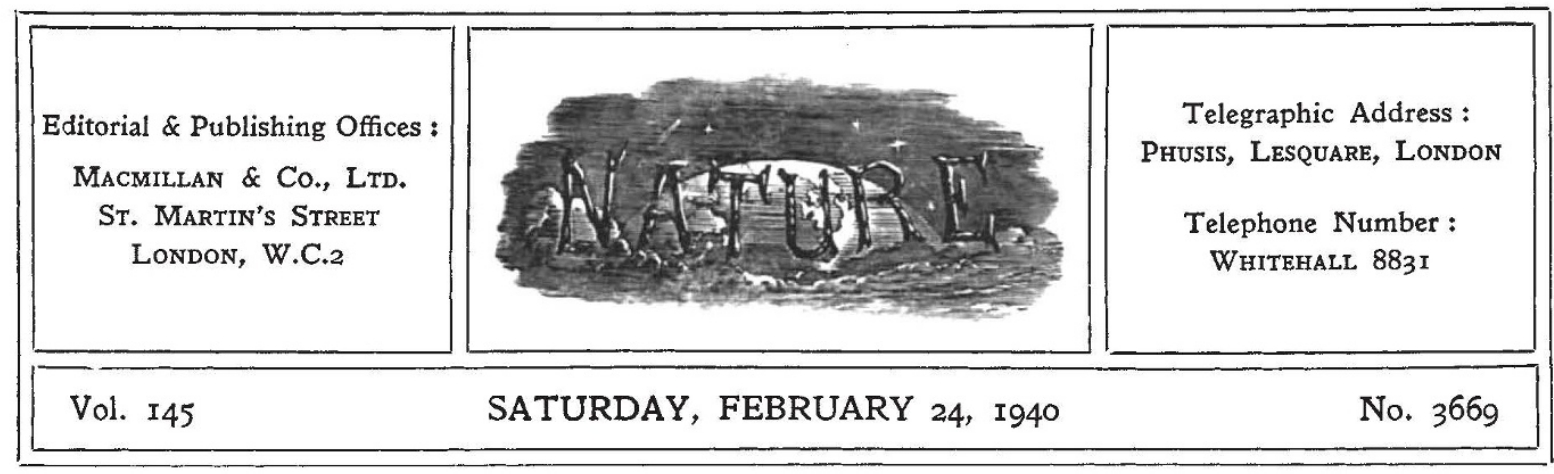

\title{
SCIENTIFIC MANAGEMENT IN ADMINISTRATION
}

$\mathrm{I}^{\mathrm{N}}$ $\mathrm{N}$ the reviews of the progress of the War which have been given from time to time by the Prime Minister in the House of Commons, the preliminary testing of many of the plans drawn up for the organization of the nation in time of war has been revealed. In these reviews, however, the actions of the armed forces or diplomatic matters have figured largely, and the home front as a whole has scarcely received the attention it merits. Particular aspects have been noticed, but the balanced and critical view of the whole economic effort of the nation, which is one of the main points in the argument for a Ministry of Economic Affairs, has been lacking.

Accordingly a broadsheet on the home front issued by Political and Economic Planning (P E P) a few weeks ago is the more welcome for the careful survey of the position and its constructive criticism of matters on which Government spokesmen have said little or nothing. The first of the subjects reviewed in this broadsheet, that of the higher machinery of Government-the functions of the Supreme War Council and the War Cabinet-has also been touched upon in two admirable articles by Mr. Hugh Quigley and Mr. L. Urwick in successive numbers of Industry Illustrated.

The P E P broadsheet, reviewing the establishment of five new ministries for war purposes and the vast new functions of three other departments, points out that the Cabinet secretariat remains the only body concerned with co-ordination over the whole field. While the appointment of Lord Stamp as adviser to a Cabinet Committee on Economic Co-ordination shows a recognition of the importance of planning an economic policy on a mich wider basis, the new office in its present form does not constitute an Economic General Staff. Moreover, the development of regionalism in civil defence holds immense implications for a possible peace-time reorganization of our administrative system.

Mr. Quigley's and Mr. Urwick's articles make interesting comment on the question put by P E P, whether the Civil Service can meet the greatest demands made on it since it assumed its present form, and adapt itself to the new conditions with their primary call for decisions and planning. $\mathrm{Mr}$. Quigley, emphasizing the importance of the efficient conduct of industry and of fitting the needs of war to an industrial machine which is allowed to develop normally and with the minimum interruption, makes the point that regulations tend to conceal the need for initiative and bold planning, when in truth more efficient management is needed.

No country appears to have made any serious effort to determine what are good and valuable industrial products in a period of war and what are bad and non-essential. Such knowledge, however, is basic for the efficient use of a country's industrial resources, and this kind of assessment requires the experience and knowledge of those in control of industry. Accordingly, Mr. Quigley urges the importance of bringing management into consultation to ensure the mainteriance of the important volume of normal production, and to determine the limits beyond which any strain on industry or any further loss of its man-power would be a source of dangerous weakness.

Mr. Urwick, while endorsing Mr. Quigley's argument as to the support which industry and management could render in maintaining the economic life of Great Britain in a planned and ordered relation to the whole national effort, lays his main 
stress on the value of the principles and practice of scientific management in solving a whole series of difficulties now facing civil, military or naval authorities. Little progress has yet been made in the application of such principles and practices to the task of government, and Mr. Urwick indicates two directions in which scientific management could give important assistance. The first of these concerns ministerial co-ordination. At the very top, the British Government affords an example of infringement of the vital principle of span of control, according to which no man can co-ordinate effectively the work of more than five subordinates whose work interlocks. He urges that a true War Cabinet of half a dozen senior ministers without departmental responsibilities, giving continuous attention to policy and each responsible for coordinating a group of departments dealing with some special aspect of the national effort, is a necessity for the effective conduct of the War. Existing arrangements are technically faulty and therefore fundamentally unworkable.

Mr. Urwick's second suggestion, concerning the assistance which scientific management could give in the training and control of clerical staff in the Army, is illustrative of a number of directions in which the application of modern management principles could be of service in fields where administration generally is probably as efficient or more efficient than in industry. The importance of utilizing such services grows as the field over which control becomes essential is extended, and as the checks on autocracy are weakened through the suspension of municipal or parliamentary elections, or the disappearance of local initiative and radical modification of the whole basis of local government.

To neglect such matters is to court disaster, or at least to imperil the very work upon which we depend for the sustained effort and sacrifices demanded in a protracted struggle. Mistakes have already been made, as in the indefensible commandeering of schools and hotels, which have more seriously damaged the credit of the Government than its spokesmen care to admit. The absence of reform or evidence of contrition in such matters as these has consequences which are not the less serious because they are not immediate, and they may easily sap confidence at the very moment it is most essential.

Criticism in Great Britain of the control already exercised is indeed directed, not against the principle of control, but against the way in which some controls have been effected. The authors of imperfect plans-and the bunglers of good planscannot claim immunity from constructive criticism merely because we are at war. On the contrary, the onus lies on those who designed or are administering the controls to say where criticism is not justified. That such criticism has frequently been justified by its results and led to the withdrawal or modification of such schemes as those for the control of fish marketing, war risks insurance, or the Ministry of Information, is one of the most hopeful signs that the Government is not unresponsive to public opinion or unmindful of the necessity of safeguarding the liberty of the subject and inviting the co-operation of the public.

The most serious effect of such errors of judgment as the commandeering of hotels and schools is not the individual hardships involved, or the general irritation at stupid blundering, but the lack of confidence engendered in the smooth working of the vast national plans as a whole. The P E P broadsheet does not, with all its constructive criticism, suggest that there is anything essentially wrong with the principles of our war-time planning, though it indicates details in which criticism and public co-operation might improve matters. It does indicate, however, the existence of conflicting orders and a lack of co-ordinating authority, and the necessity of facing a drastic revision of traditional policies.

These points are specially stressed in relation to finance, to the planning of priorities, of man-power, agricultural policy and food control. All these, moreover, are clearly interlocked. In regard to finance, the war budget relies almost completely on the old system of taxation. The vital issue is to decide how much of the national income can be taken for war purposes, or what combination of price control, inflation, taxation and borrowing should be used for diverting enough of the national income from civil to military needs. One of the most difficult problems of war finance is how to control the dislocating effect of a vast increase in Government expenditure and the consequent widespread distribution of purchasing power at a time when a large proportion of the country's resourceslabour, capital equipment and raw materials-is diverted from the provision of goods for current consumption to war purposes. The suggestion recently put forward by Mr. J. M. Keynes for dealing with this question of control of consumption by compulsory saving is a departure from the traditional policy which deserves careful 
examination, although good results are already being obtained by voluntary effort.

Such questions of finance are linked inextricably with the maintenance of export trade, and the question of exports and the distribution of export effort between the old heavy industries already fully engaged with war work and the newer light industries. It affects questions of prices, wages and profiteering and the planning of priorities. Clearly the Central Priorities Department should be used to plan the whole economic output of Great Britain and not just the supplies of the defence services. The needs of the civil population and of the export trades must also be considered and balanced against each other, if the most efficient use of available resources is to be secured.

Planning the utilization of Great Britain's resources of man-power to the best advantage is the function of the Ministry of Labour in consultation with the Labour Sub-committee of the Ministerial Priorities Committee. There is already evidence that lessons have been learned from the blunders of twenty-five years ago, and the compilation of the National Register should provide information for planning man-power much more comprehensively than before. It is doubtful, however, whether the true value of the Register in the scientific organization of a civilized community is yet realized. The Central Register has already proved its usefulness in placing certain classes of scientific workers where their services are most urgently needed; but it should be remembered that the whole register is experimental, and that experience is likely to suggest many improvements and extensions.
Complex problems of labour are bound to arise not merely in the munitions industry but also in agriculture and through the relations between rail and road transport, where fundamental reconsideration of the positions of both industries is urgently required. In agriculture, itself so closely linked with the question of food supply and rationing, a general clarification of aims is urgently required. Modern industrial, economic and scientific technique finds little reflection in much of the farming still practised ; the pooling of all available knowledge in the service of war-time efficiency on the farm is as important as pooling labour, machinery, horses or even the land where the units are now too small to operate economically.

If, however, control and rationing are to be accepted with good grace, there must be confidence that adequate co-ordination of the national effort exists, and that steps have been taken to secure the scientific and impartial utilization of the full resources of the nation in the one purpose that counts. Rationing, whether of petrol or food or other commodities, will be accepted without demur so long as the private user does not feel that he is deprived of supplies for officials to waste. Scientific workers, who have their own contribution to make in so many widely different fields, should not therefore be unmindful of this supreme need for insisting that the fullest use is made of the methods and principles which scientific management puts into our hands, for securing the due co-ordination and efficient operation of any enterprise in the fulfilment of its purposes, whether they be those of a private business or of a nation at war.

\section{THE ORIGIN OF LIFE}

Life's Beginning on the Earth

By Prof. R. Beutner. Pp. $x+222$. (London: Chapman and Hall, Ltd., 1939.) 12s. $6 d$. net.

THE "Manager of the Performance" as Prof. Beutner invites his readers to regard him, apparently supported by the Provost, Dean and staff of his Institute, stands on the stage before the curtains are drawn for the film. The technique is useful in that exact references to literature are unnecessary and concentration of eye and brain is secured. There is also no index and the mind is not usually disturbed by references to the sources from which the pictures are derived. These lapses make the film less useful to scientific men, while causing less strain on the commencing students of science and medicine for whom it is perhaps primarily intended. To these, all comparisons between the reactions of living and non-living matter cannot but present helpful analogies, which may well prove of great value to medicine, as suggested in the epilogue. The subject, however, has a wider appeal, for evidently certain of its sides have been the author's research life for many years. It deserves more than a passing reference.

As a practical presentation we suggest that the manager has reversed the order of the pictures of 